\title{
Business Autonomy through Entrepreneurship Models of People-Oriented Economy in Coastal Areas
}

\author{
Arie Frits Kawulur, Ramon Arthur Ferry Tumiwab, Merry Christie Natalia Rumagit
}

\begin{abstract}
The aim of this study is to examine entrepreneurship model of people-oriented economy in business groups in coastal areas to have autonomy in order to increase business income. The research method utilized in this study was the experimental method with one group pretest-posttest experiment design. Respondents in this study are 112 people from 14 business groups on the coast of North Minahasa Regency, North Sulawesi Province which were selected via purposive sampling technique. The analysis technique of the research employs a two-difference test with a t-test. The results exhibited that there were significant differences before and after entrepreneurial training based on people-oriented economy. This research reveals that there is an increase in knowledge, attitudes and skills of the members of the business groups in terms of economic potential of Natural Resources at sea and coast, Product-making technology based on local potential, Innovation and "Mapalus" Culture.
\end{abstract}

Index Terms: Business Autonomy, Human Resources, Natural Resources, Product Technology, Innovation, and “Mapalus” Culture.

\section{INTRODUCTION}

The problem of poverty has alarmed every country in order to reduce it. Economic development strategy is the key to reduce poverty and plays an important role in solving the problem. In reducing poverty, the economic development strategy particularly in rural areas, implements subsidies in agriculture and social sectors. Hence, results show that there is progress in decreasing substantial poverty by implementing input subsidy assistance to agriculture and social assistance to poor people. (Lowder, Bertini, \& Croppenstedt, 2017). Moreover, subsidies in agriculture is able to decrease poverty rate greater than subsidies in other fields, as the research from Christiaensen and Martin (2018) emphasizes the assessment that growth in agriculture on average reduces poverty more than the amount equivalent to growth outside agriculture.

Indonesian government has a dominant and enormous role in the economic approach to poverty alleviation in Indonesia. The poverty rate has declined, but not significantly. Revitalizing poverty alleviation programs by encouraging important non-economics as social capital becomes essential.

Revised Manuscript Received on September 22, 2019.

Arie Frits Kawulur, Economics Department, Economic Faculty, Universitas Negeri Manado, Indonesia, ariekawulur@unima.ac.id

Ramon Arthur Ferry Tumiwab, Management Department, Economic Faculty, Universitas Negeri Manado, Indonesia

Merry Christie Natalia Rumagit, Economics Department, Economic Faculty, Universitas Negeri Manado, Indonesia.

This is studied by analysing every social bond which bridges the dimensions of poverty alleviation and guards the community from the vulnerability of being underprivileged another time. (Yamin \& Dartanto, 2016). Regarding social protection for disadvantaged and vulnerable households, Desai and Rudra found in their research that the agricultural sector particularly those related to food provided better social protection than the manufacturing sector, countries with manufacturing trade surpluses are more likely to experience reduced coverage towards social protection (Desai \& Rudra, 2018).

In Indonesia, it is still the foremost problem that the biggest contribution which makes the underprivileged is still in the matter of primary needs. The role of food commodities on the poverty line is far greater than the role of non-food commodities (housing, clothing, education, and health). The contribution of the Food Poverty Line to the Poverty Line in March 2018 was recorded at 73.48 percent. This figure is going up compared to the conditions in September 2017, which amounted to 73.35 percent. The types of food commodities that have a major influence on the value of the Poverty Line in urban and rural areas such as rice, filtered clove cigarettes, broiler eggs, chicken meat, instant noodles, and granulated sugar. Meanwhile, non-food commodities which have a large effect on the value of the Poverty Line in urban and rural areas are housing, gasoline, electricity, education, and toiletries. During the period September 2017 - March 2018, the number of underprivileged people in urban areas fell by 128.2 thousand people (from 10.27 million people in September 2017 to 10.14 million people in March 2018), while in rural areas it dropped by 505 thousand people (from 16.31 million people in September 2017 to 15.81 million people in March 2018). The percentage of poor people in urban areas in September 2017 was 7.26 percent, down to 7.02 percent in March 2018. Meanwhile, the percentage of poor people in rural areas in September 2017 was 13.47 percent, went down to 13.20 percent in March 2018. (Central Statistics Agency, 2019, https://www.bps.go.id/).

The problems in this research location are the coast of North Minahasa Regency, the coastal area of East Likupang District and West Likupang District. It appears that underprivileged families are still at $59 \%$, there are even villages which stand out as underprivileged families in Likupang II with $77 \%$,

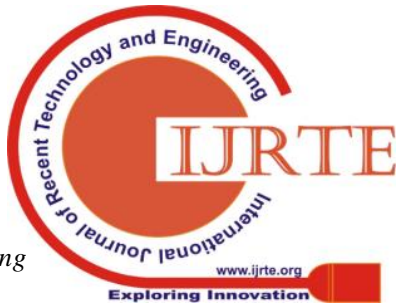


Lihunu village is still $64 \%$, Kinunang village is $71 \%$, and Likupang Kampong Ambong is 66\%. (Document Profile of Village of East Likupang and West Likupang Districts, 2017) although it has high maritime potential. There are still numerous fishermen communities in this area who are fishing traditionally and unable to grow their businesses, particularly for those who merely work as laborers or the local area call it "masanae", they have not been able to meaningfully increase their income. In addition, there are still wide areas for agriculture in the coastal areas, both perennials and seasonal crops such as sweet potatoes, bananas, rice, corn, peanuts, etc. Derivative products from marine and agricultural products are enormous if managed, but this business opportunity has not been utilized optimally, hence, families on the coast have not been able to increase their income.

Those are the reasons why high unemployment and poverty rates are still one of the most socio-economic problems of concern that disrupt the implementation of benefits, particularly for women in the socio-economic field. After analysing trends in changes and correlations between unemployment and poverty levels in 28 EU countries, researchers found that the chain of unemployment and poverty differed, although it was often highlighted that unemployment was one of the main reasons for poverty. Nevertheless, the finding of the unemployment rate of women at risk of poverty reveals that there is a strong direct relationship (Kiaušienè, 2015). This becomes a reference for Indonesia in increasing income for the families of farmers and fishermen on the coast to provide a significant role for women fisher and farmers to have businesses which support to increase the income of their family.

Countries in the world are competing to achieve high incomes and income inequality by narrowing the inequality of community's income. Findings suggest that countries with lower inequality and higher incomes exhibit a greater ability to change the growth rates that contribute on poverty reduction (Fosu, 2017). The implication is that it needs to increase productivity in agriculture, industry, and services to reduce global poverty. In poor countries, an increase in agricultural productivity including maritime normally has the effect of reducing poverty which is greater than the increase in industry or services. This difference goes down when the average income rises, but the agricultural sector becomes smaller due to a shift in the economic sector, thus agricultural productivity growth becomes less effective in decreasing poverty (Ivanic \& Martin, 2018).

Thus, the marine sector including agriculture plays an important role in reducing unemployment and poverty. However, the contribution of output in the marine sector in Indonesia is still low in term of the workforce who earn a living in the sea which is only $4.12 \%$ compared to other sectors although it has enormous potential, therefore it is recommended that fisheries, marine industry, marine infrastructure, and marine services are the main sectors which are very potential to be developed (Nurkholis et al., 2016).

Looking at the vast sea in Indonesia, the economic prime mover should be based on the marine sector. However, the real data shows that the marine sector is still low in its contribution to gross domestic product at $28 \%$ compared to Japan with a smaller sea area than Indonesia, but Japan's sea area can contribute around 55\% of their GDP. Therefore, the potential of the sea in Indonesia is very high and has not been optimized, including in North Minahasa Regency. Based on the potential of the marine sector and coastal potential that have not been fully managed, the researchers conducted a study to develop a model of people's economic empowerment in the marine and coastal sectors. Coastal tourism is essential because many countries have felt its positive and encouraging contributions to the growth of development. Tourism is one of the largest industries in the world and coastal tourism is the fastest form of growth tourism with a marked growth over the past decade. The importance of the economy of coastal tourism cannot be denied and is a major source of income for many countries and regions. This creates the key impacts on socio-cultural, economic, physical and environmental conditions in many coastal areas, which are closely related to growth in that area at last (Lakshmi \& Shaji, 2016).

Indonesian higher education exists with one of its goals is to help the community in order to deal with globalization. Community service carried out by universities must take the form of collaboration between various parties to work together for the improvement of Indonesia. In relation to this, the support of all parties is required, including support in the form of community service activities conducted by universities (Marwasta, 2017).

Previous research shows that the ideal model of community-based coastal area management is held by the right synergy and interaction between the government, the community and the value of local wisdom. Empowerment of coastal communities in developing models of coastal area management is also very vital to do with the intention of encouraging their autonomy. The use of this model has advantages because the active participation of coastal communities can increase income, maintain the sustainability of the coastal environment, and provide freedom for coastal communities to develop and manage marine resources in accordance with the potential, characteristics and social culture of the community. The active participation of coastal communities also gives hope for decreasing the problem of poverty which leads to the realization of justice and the welfare of coastal communities (Agung Istri Ari Atu Dewi, 2018).

Eventually, the concept of entrepreneurship-based economy on the coastline which the authors test in this research are more applicable as exhibited below:

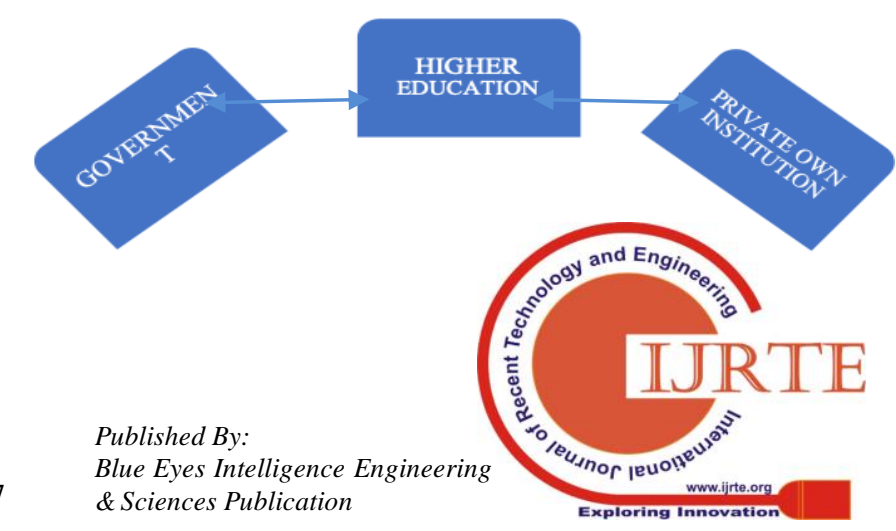



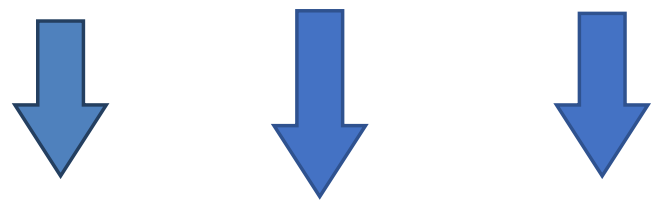

MINDSET CHANGE

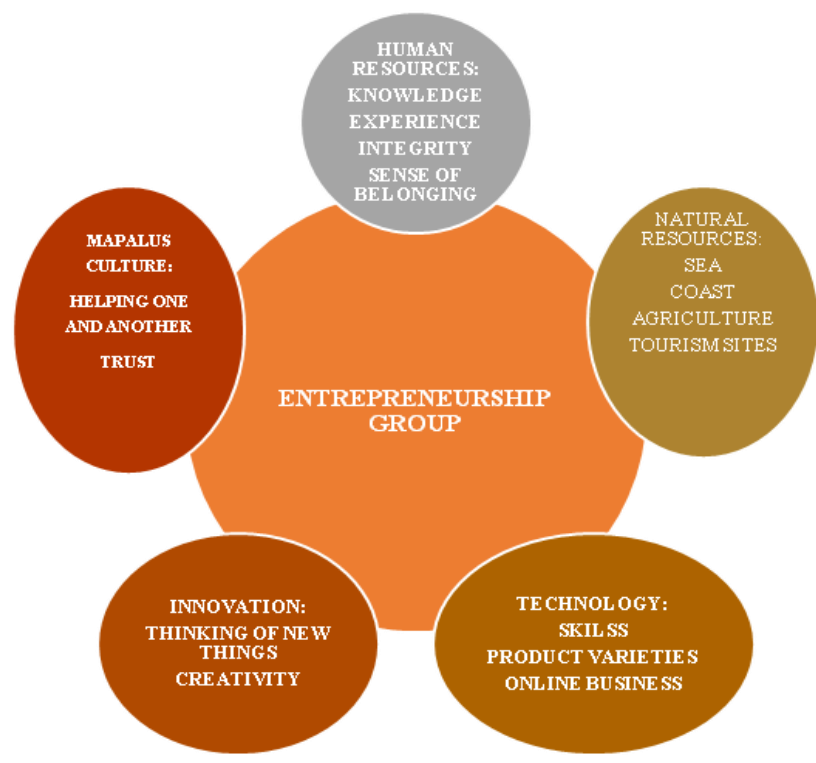

Fig 1: model-based entrepreneurial concepts of economic population list on the coast

The role of each party shown above can be maximized. Higher education (researcher) produces a model of entrepreneurial concepts of training and mentoring, while the private sector supports fund and mentoring, and the government helps with their regulation about ease of credit and with the synergy of business assistance. Each party coordinates in the initial process until mentoring. The researchers conduct the "Change of Mindset" process for everyone who joined the entrepreneurial group which was nurtured.

The mindset of the entrepreneurial groups are formed to do business commercially by giving training to superior human resources (knowledge, experience, skills, integrity, and ownership of business) regarding the potential of natural resources which can be commercialized, practicing "Mapalus" culture, innovation training (creativity, thinking of new things), and training in the use of various product-making technologies even other businesses developed include the use of online technology in business and marketing. Therefore, it is expected that this model will have an impact on business sustainability and autonomy.

\section{LITERATURE REVIEW}

The economic crisis that Indonesia experienced in 1997/1998 and 2008/2009 shows that small and medium enterprises have proven to be autonomous business groups which have strong resistance. Regrettably, this autonomous business group, particularly small and micro businesses with low income find it difficult to obtain capital or financing from banking institutions due to lack of financial history (Ibrahim
\& Verliyantina, 2012). However, business autonomy does not always have maximum profit or produce a product with a lower price. The excellence in business is a complex approach from an economic, technical, and social point of view, which is called business excellence (Ghicajanu, Irimie, Marica, \& Munteanu, 2015).

Business autonomy can be realised by having business passion and entrepreneurial skills which are established such as self-confidence, leadership, creative thinking in problem solving, efficient and effective in implementing plans, entrepreneurial and business knowledge, analytical thinking, balancing skills between personal and business life, and flexibility business (Xavier, Ahmad, Nor, \& Yusof, 2012). Moreover, the need for business knowledge, especially in the development of micro and small businesses in the field of coastal tourism, is essential as stated in this research article. It discusses the scope of welfare that focuses on tourism potential to be developed in business, particularly opportunities for tourism entrepreneurs in the coastal region. Besides, it was found that the involvement of the public or the community and researchers building business processes via training business knowledge to assist business development and to adapt many things of potential that exists in coastal tourism areas will expand their offerings to a wider market (Page et al., 2017).

This has inspired the design of this research so that business actors on the coastline have business autonomy. It is also required to treat entrepreneurial models by optimizing the potential of coastal natural resources, innovation, utilization of technology, and the application of a "Mapalus" culture in entrepreneurship.

\section{A. Natural Resources in Entrepreneurship}

Indonesia as the largest archipelagic country in the world has a focus on developing coastal areas through numerous programs such as Minneapolitan (fish city). The main activity currently in the Minneapolis settlement that supports the Minneapolitan program is community empowerment through fishing and fisheries processing. Over the last few years, there has been a decrease in the amount of fisheries production and an increase in processing costs due to global climate change and unsustainable exploitation of fishing and daily life in settlements in Brondong. This phenomenon impacts community's stability and resilience particularly those who live in the Brondong coastal settlements (Martadwiprani \& Rahmawati, 2014).

Similarly, the potential of marine fisheries (marine natural resources) in North Sulawesi Province is large but still has limitations both in fishing at sea and in processing in the fishing industry to produce products for export, specifically those that are well-known from raw materials for tuna. This is strengthened by the research of Fatma (2015) who found that in addition to the availability of tuna preservation, the development of the fish processing industry in Indonesia still has problems. Those are the limitations of ships with hygiene standards which affect the quality of results, the low awareness level of product

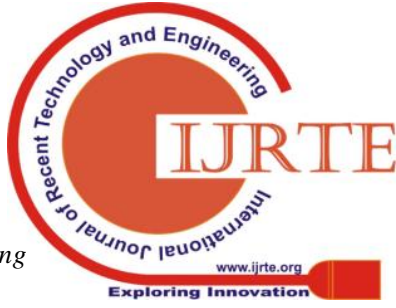


quality, and the priority of the tuna business which is limited to fresh and frozen tuna, and it has not yet reached at advanced industrial processes. These obstacles reduce the development of the canned tuna industry. Thus, government support is required to ensure the availability of raw materials, support for facilitation in the canning industry and upstream support for fishermen, particularly the equipment to catch tuna.

Similarly, the coastal areas have natural potential which can be developed to release local communities from poverty. The purpose of the development of tourism in Indonesia is to reduce poverty, preserve nature and the environment. The resources are able to improve the welfare of its people from the tourism sector, however there are many things that must be considered to achieve the development of the tourism business sustainability in the future. There are numerous problems that arise as a result of tourism business development. Research (Sutawa, 2012) aims to show how local community empowerment can be the main factor for tourism development because empowering and engaging the community in tourism development will safeguard their culture and nature so that sustainable tourism development will become achieved and maintained eventually.

Indonesian coast has natural resources which have the potential to be developed into a place of business for local communities. The process of empowering coastal communities should be involved in business to optimize the potential of natural resources which provide economic added value for the community.

\section{B. Innovation in Entrepreneurship}

Innovation is a thought process to solve complex problems and generates original things. In the production process utilising appropriate technology requires innovative thinking to produce quality and attractive products for customers. Pärttö and Saariluoma's research (2012) reveals that the innovation process is comprehended as a thought process in solving complex and multi-phase problems to produce new and surprise solutions. Process of innovative thinking consider other contributing factors such as long-term thinking and the comprehension of other people's perspectives.

Innovation activities in entrepreneurship should provide added value in business autonomy. The added value in the form of economic, social and environmental values, as well as innovation including traditional businesses are able to provide an increase in the value of social awareness related to the role of the internet which encourages innovation in business (Weissbrod \& Bocken, 2017; Grabowska \& Sukiennik, 2015). Similarly, rural areas particularly in coastal areas which have business potential in the tourism sector require innovation in the development of coastal villages from an economic, social and environmental perspective. According to Bouchon and Rawat (2016) that innovative practices were initiated by training in rural communities' projects taking samples in Indonesia, Thailand and Malaysia to improve socio-economic development community and tourism also build entrepreneurs. The results of the research found that training for rural communities' projects could be extended to other rural areas in the ASEAN region.

Thus, the factor of innovation plays a significant role in creating more successful entrepreneurs, particularly the people in rural areas, especially the growth areas of tourism on the coast.

\section{Technology In Entrepreneurship}

The implementation of technology to business units is intended to generate efficiency in production and to improve product quality. The research about the development of Tuna Processed Business in Pacitan District, Indonesia revealed alternative development strategies including maintaining product quality to increase customers loyalty, technological innovation to improve production efficiency, and increase the ability to access capital (Setyowati, Rahayu, \& Ishartani, 2016). Technological developments play an essential role in the success and competitiveness of companies. This can be ensured through technological innovations to improve product quality and service, market control and products which attract customers (Sosnowski, 2014; Hamenda, 2018).

The industry era 4.0 encourages every business including businesses on the coast to utilize digital technology in order to marketize its products as well as in the process of its production. The digital business model has the potential to be implemented because the internet network has reached in the remote coastal areas in North Minahasa regency. Thus, digital business and the use of start-up technology have the potential to be implemented for the development of entrepreneurship by training for human resources or business actors who have insufficient competence so that business performance can be improved (Härting, Reichstein, \& Schad, 2018); (Millers \& Sceulovs, 2017); (Janáková, 2015).

Developed countries create and utilise technological developments in the era of revolution 4.0 so that business persons are encouraged to generate technology to grow and become autonomous and sustainable businesses.

\section{D. "Mapalus" Culture in Entrepreneurship}

Communities' culture strengthens social capital which will contribute to sustainable livelihoods that are indicated by the improving economic life of the community. Sustainable livelihood is a way of thinking that focuses on human development to restore and enhance the capabilities and social capital that is owned in the present and the future.

The research on the coastal communities of Medan City about the social capital relationship found that social capital significantly affects business management in the coastal zone of Medan, however, business management does not significantly affect livelihoods in a sustainable manner. Nevertheless, social capital significantly affects livelihoods in a sustainable manner primarily (Maas, Sirojuzilam, Erlina, \& Badaruddin, 2015).

Indonesia is a country that is rich in family-oriented culture as social capital. Every 
aspect that is characterized by a family is valued and creates a unique culture of the country and is not seen in other countries (Rachmania, Rakhmaniar, \& Setyaningsih, 2012). Likewise, the Minahasa tribe has a "Mapalus" culture in North Sulawesi.

Mapalus is a working togetherness that has become a culture in the life of the Minahasa tribe. Mapalus shapes the character of human / society in its implementation indirectly to be better individuals. This is demonstrated through the act of joint work, mutual respect for one and another, obeying every rule in a Mapalus group, and helping each other in various activities both in activities (party / thanksgiving for the results of their fields) or in grief activities (death) (Tangkudung \& Senduk, 2017). The results of research from Wuryaningrat, Kawulur and Kumajas (2017) found that in that culture, people give assistance to cook and make tents. When harvest comes to the priest's land, people will help with pleasure, even though for other jobs, money has degraded Mapalus values.

There are three Mapalus forms that have real activities, namely Money Mapalus, Farming Mapalus, and Art-Culture Mapalus. Communities and local governments can play a more intensive and more active role in numerous Mapalus activities in their daily lives in order to meet human resource needs, welfare and family needs (Turang, Suman, Mandang, \& Soemarno, 2012).

Therefore, a Mapalus culture that strengthens social capital that characterizes the efforts in the midst of the people of North Sulawesi, especially North Minahasa regency in order to achieve business sustainability creates business autonomy.

Finally, authors made an estimation in this research by formulating a research hypothesis as following.

1. There were significant differences before and after training on the potential of natural resources in entrepreneurship.

2. There are significant differences before and after training on technology in entrepreneurship.

3. There are significant differences before and after training on innovation in entrepreneurship.

4. There are significant differences before and after training on "Mapalus" culture in entrepreneurship.

5. There are significant univariate differences before and after training about the potential of natural resources, innovation, technology, and the culture of "Mapalus" in entrepreneurship for all members of business groups in the coastal area of North Minahasa regency.

\section{METHODOLOGY/MATERIALS}

This research utilises the experimental method, which is to treat members of the business group on the coast of North Minahasa Regency, particularly the coastal areas of North Minahasa both east and west. The research design implemented was experimental design based on the treatment of training for people who are members of a business group, namely one group pretest-posttest experiment design. Respondents in this research are 112 people from 14 business groups on the coast of North
Minahasa Regency, North Sulawesi Province. Respondents were selected through purposive sampling technique. The analysis technique used in this research is to test the differences in the two averages before and after training by testing the hypothesis utilizing the t-test.

\section{RESULTS AND FINDINGS}

\section{A. Normality Assumption Data}

In parametric statistics, the data should be confirmed for normality with the intention of meeting the requirements as one of the parametric tests. Therefore, data from 4 variables are tested as follows:

Table 1: Test the Normality of Natural Resources Data

\begin{tabular}{llr}
\hline & & sda \\
\hline $\mathrm{N}$ & & 112 \\
Normal & Mean & 31.40 \\
Parameters $^{\mathrm{a}, \mathrm{b}}$ & Std. Deviation & 1.545 \\
Most Extreme & Absolute & .142 \\
Differences & Positive & .135 \\
& Negative & -.142 \\
Kolmogorov-Smirnov Z & 1.500 \\
Asymp. Sig. (2-tailed) & .022 \\
\hline
\end{tabular}

a. Test distribution is normal.

b. Calculated from data.

The table above displays the results of the One-Sample Kolmogorov-Smirnov Test. Asymp Value. Sig. (2-tailed) $0.022<\alpha 0.05$ which means that natural resource data is normally distributed.

Table 2: Normality Test for Technology Data

\begin{tabular}{|ll|r|}
\hline & & \multicolumn{1}{|c|}{ Technology } \\
\hline $\mathrm{N}$ & & 112 \\
Normal & Mean & 36.42 \\
Parameters $^{\mathrm{a}, \mathrm{b}}$ & Std. Deviation & 1.824 \\
Most Extreme & Absolute & .150 \\
Differences & Positive & .109 \\
& Negative & -.150 \\
Kolmogorov-Smirnov Z & 1.588 \\
Asymp. Sig. (2-tailed) & .013 \\
\hline
\end{tabular}

a. Test distribution is Normal.

b. Calculated from data.

The table above presents the results of the One-Sample Kolmogorov-Smirnov Test. Asymp Value. Sig. (2-tailed) $0.013<\alpha 0.05$ which means that the technology data is normally distributed.

Table 3: Normality Test for Innovation Data

Innovation




\begin{tabular}{llr}
\hline $\mathrm{N}$ & & 113 \\
Normal & Mean & 31.50 \\
Parameters $^{\mathrm{a}, \mathrm{b}}$ & Std. Deviation & 1.808 \\
Most Extreme & Absolute & .130 \\
Differences & Positive & .107 \\
& Negative & -.130 \\
Kolmogorov-Smirnov Z & 1.383 \\
Asymp. Sig. (2-tailed) & .044 \\
\hline
\end{tabular}

a. Test distribution is normal.
b. Calculated from data.

The table above reveals the results of the One-Sample Kolmogorov-Smirnov Test. Asymp Value. Sig. (2-tailed) $0.044<\alpha 0.05$ which means that the innovation data is normally distributed.

Table 4: Normality Test for Cultural Data

\begin{tabular}{llr}
\hline & & Culture \\
\hline $\mathrm{N}$ & & 112 \\
Normal & Mean & 59.38 \\
Parameters $^{\mathrm{a}, \mathrm{b}}$ & Std. Deviation & 2.596 \\
Most Extreme & Absolute & .155 \\
Differences & Positive & .105 \\
& Negative & -.155 \\
Kolmogorov-Smirnov Z & 1.644 \\
Asymp. Sig. (2-tailed) & .009 \\
\hline
\end{tabular}

a. Test distribution is normal.

b. Calculated from data.

The table above shows the results of the One-Sample Kolmogorov-Smirnov Test. Asymp Value. Sig. (2-tailed) $0.009<\alpha 0.05$ which means that cultural data is normally distributed.

Furthermore, statistical tests were conducted to determine the effect of differences in the similarities of the two averages in the treatment before and after the training of the participants' training, in which all members of the business groups scattered in the coastal area of North Minahasa District, Likupang Raya. The test of the effect of the difference is divided into two, that is the partial test based on factors or variables that are practiced with bivariate t-test and the test simultaneously perceives the effect of the difference before and after training as a whole variable with the univariate t-test.

The partial test statistic with bivariate t-test is as analysis below:

\section{1) Natural Resources}

Table 5: Group Statistics Natural Resources

\begin{tabular}{crrcr}
\hline Group & N & Mean & \multicolumn{2}{c}{$\begin{array}{l}\text { Std. } \\
\text { Deviation Mean }\end{array}$} \\
\hline Value Pre & 112 & 27.48 & 2.910 & .275 \\
Post & 112 & 31.40 & 1.545 & .146 \\
\hline
\end{tabular}

The table above exhibits the Mean or Average of each group, which is in the Pre-group the value is 27.48 in which it is lower than the Post-group which is 31.40 .

Table 6: Independent Samples Test of Natural Resources

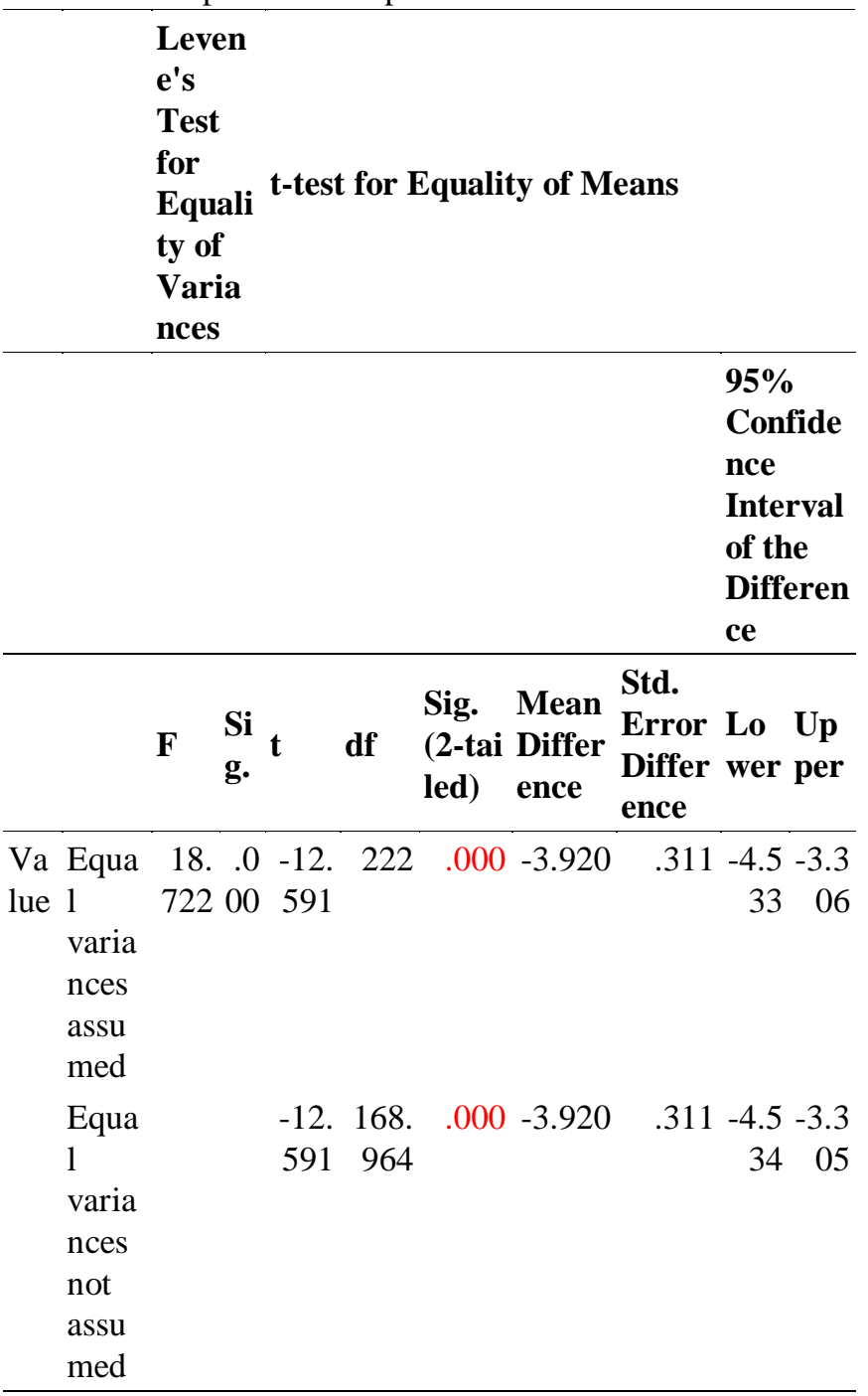

With regard to Sig (2 tailed) or $\mathrm{p}$ value, it is clear from the data above that the value of $p$ value is 0,000 which is $<0.05$, meaning that the difference is significant statistically or significant at the probability of 0.05 . Accordingly, there is a significant difference statistically in the error rate of $5 \%$ before treatment and a natural resource training for members of entrepreneurial groups on the coast.

\section{2) Technology}

Table 7: Group Statistics Technology 


\begin{tabular}{|l|r|r|r|r|}
\hline \multicolumn{1}{|c|}{ Group } & \multicolumn{1}{c|}{$\mathrm{N}$} & \multicolumn{1}{c|}{ Mean } & $\begin{array}{c}\text { Std. } \\
\text { Deviation }\end{array}$ & $\begin{array}{c}\text { Std. Error } \\
\text { Mean }\end{array}$ \\
\hline Val Pre & 112 & 33.88 & 3.995 & .377 \\
ue $\quad$ Post & 112 & 36.42 & 1.824 & .172 \\
\hline
\end{tabular}

The table above displays the mean or mean of each group, that is, in the Pre-group the value is 33.88, which is lower than the Post-group which is 36.42 .

Table 8: Independent Samples Test of Technology

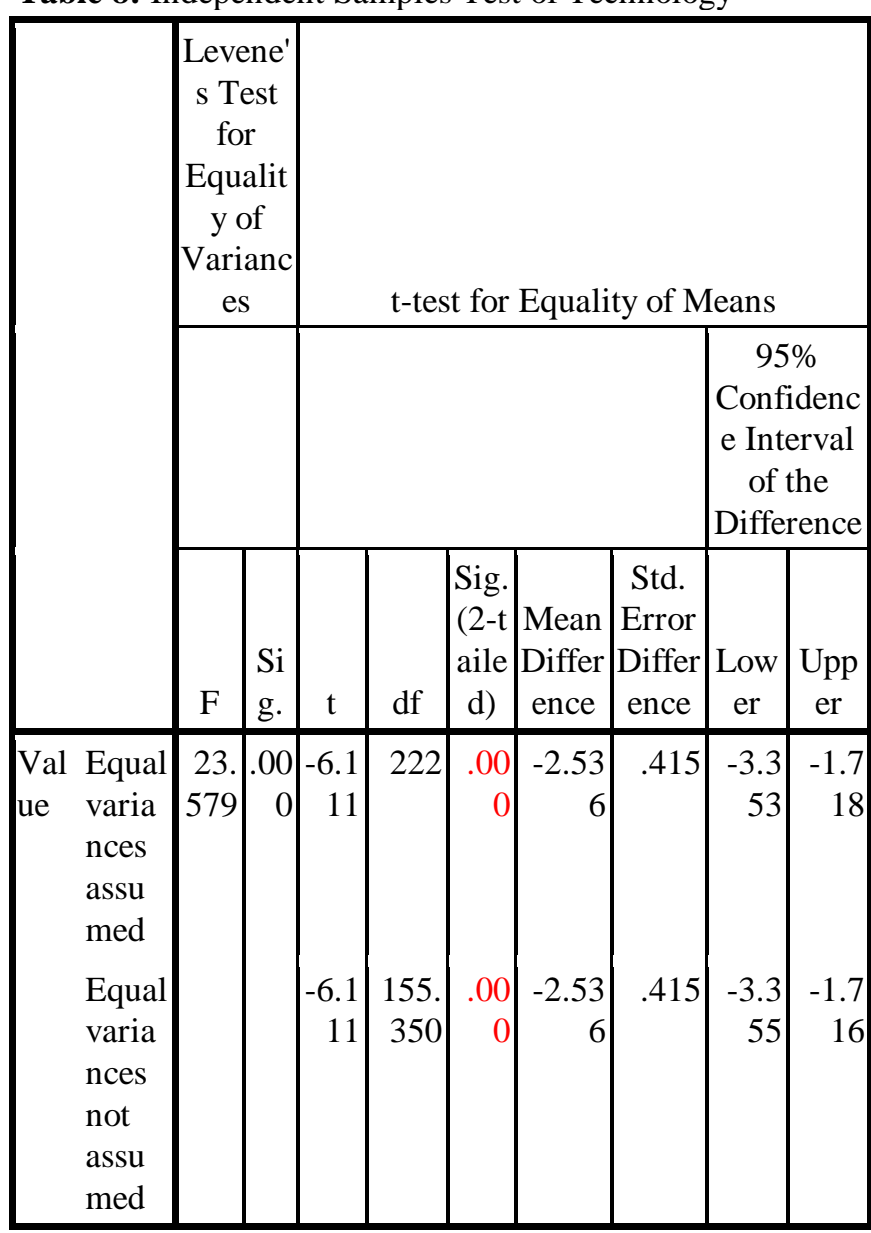

Regarding Sig ( 2 tailed) or $\mathrm{p}$ value, it is noticeable from the data above that $\mathrm{p}$ value is 0,000 which is $<0.05$, meaning that the difference is significant statistically or significant at the probability of 0.05 . Therefore, there is a significant statistically difference in the $5 \%$ error rate of treatment before and after training on technology for members of entrepreneurial groups on the coast.

\section{3) Innovation}

Table 9: Group Statistics Innovation

\begin{tabular}{|l|r|r|r|r|}
\hline \multicolumn{1}{|c|}{ Group } & $\mathrm{N}$ & \multicolumn{1}{c|}{ Mean } & $\begin{array}{r}\text { Std. } \\
\text { Deviation }\end{array}$ & $\begin{array}{c}\text { Std. Error } \\
\text { Mean }\end{array}$ \\
\hline Val Pre & 112 & 29.46 & 2.018 & .191 \\
ue Post & 112 & 31.50 & 1.816 & .172 \\
\hline
\end{tabular}

The table above presents the mean or mean of each group, which is in the Pre-group the value is 29.46 , which is lower than the Post-group which is 31.50 .

Table 10: Independent Samples Test of Innovation

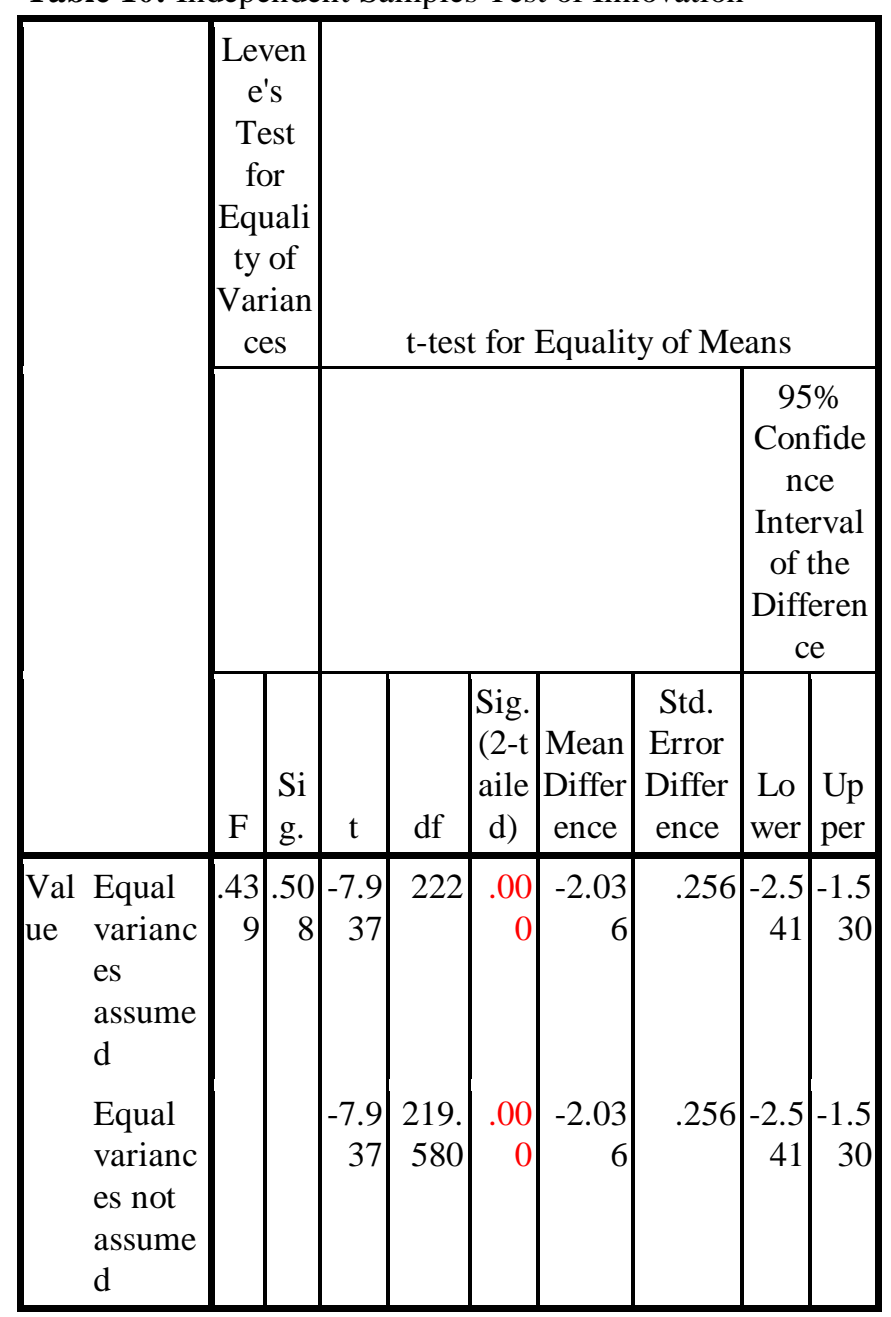

As for Sig (2 tailed) or $\mathrm{p}$ value, it is clear from the data above that $\mathrm{p}$ value is 0,000 which is $<0.05$, meaning that the difference is significant statistically or significant at the probability of 0.05 . Hence, there is a significant difference statistically in the $5 \%$ error rate of treatment before and after training on innovation for members of entrepreneurial groups on the coast.

\section{4) Culture}

Table 11: Group Statistics Culture

\begin{tabular}{|l|r|r|r|r|}
\hline \multicolumn{1}{|c|}{ Culture } & N & Mean & $\begin{array}{c}\text { Std. } \\
\text { Deviation }\end{array}$ & $\begin{array}{c}\text { Std. Error } \\
\text { Mean }\end{array}$ \\
\hline Val Pre & 112 & 54.74 & 3.984 & .376 \\
ue Post & 112 & 59.38 & 2.596 & .245 \\
\hline
\end{tabular}

The table above displays the mean or mean of each group, namely in the Pre-group the value is 54.74, which is lower than the Post-group, which is 59.38.

Table 12: Independent Samples Test of Culture 


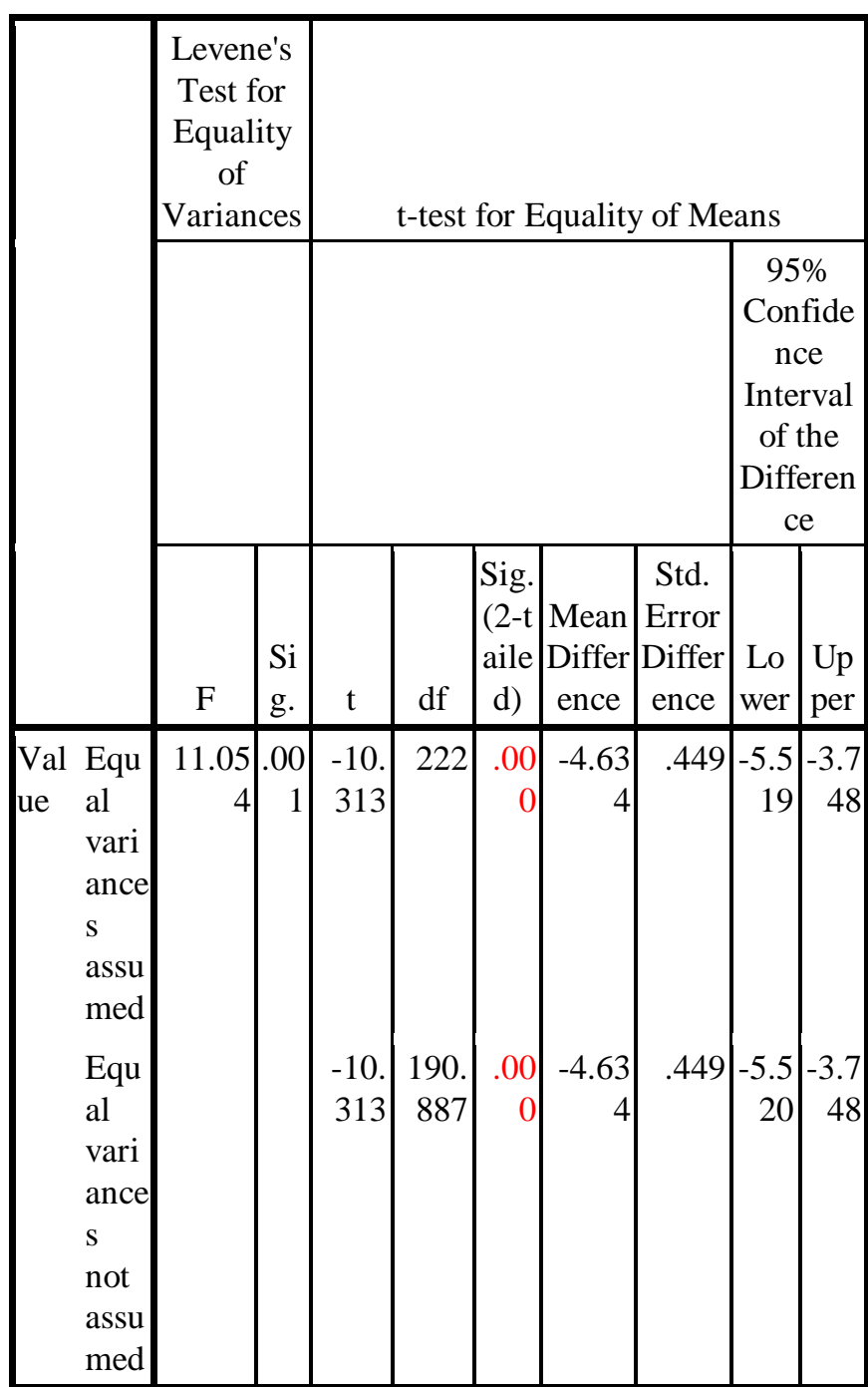

Regarding Sig (2 tailed) or $p$ value, the $p$ value is 0,000 which is $<0.05$, meaning that the difference is significant statistically or significant at the probability of 0.05 . Therefore, there is a statistically significant difference in the $5 \%$ error rate of treatment before and after training on "Mapalus" culture for members of entrepreneurial groups on the coast.

In the end, the effect of the differences was simultaneously analysed on the variables which were intervened in all participants with the univariate t-test as in the following table:

Table 13: Group Statistics Univariate

\begin{tabular}{|l|r|r|r|r|}
\hline \multicolumn{1}{|c|}{ Group } & \multicolumn{1}{c|}{$\mathrm{N}$} & Mean & $\begin{array}{c}\text { Std. } \\
\text { Deviation }\end{array}$ & $\begin{array}{c}\text { Std. Error } \\
\text { Mean }\end{array}$ \\
\hline Val Pre & 112 & 145.57 & 9.301 & .879 \\
ue $\quad$ Post & 112 & 158.70 & 5.219 & .493 \\
\hline
\end{tabular}

The table above exhibits the mean or average of each group, which is in the Pre-group the value is 145.57 , which is lower than the Post-group which is 158.70 .

Table 14. Independent Samples Test of Univariate

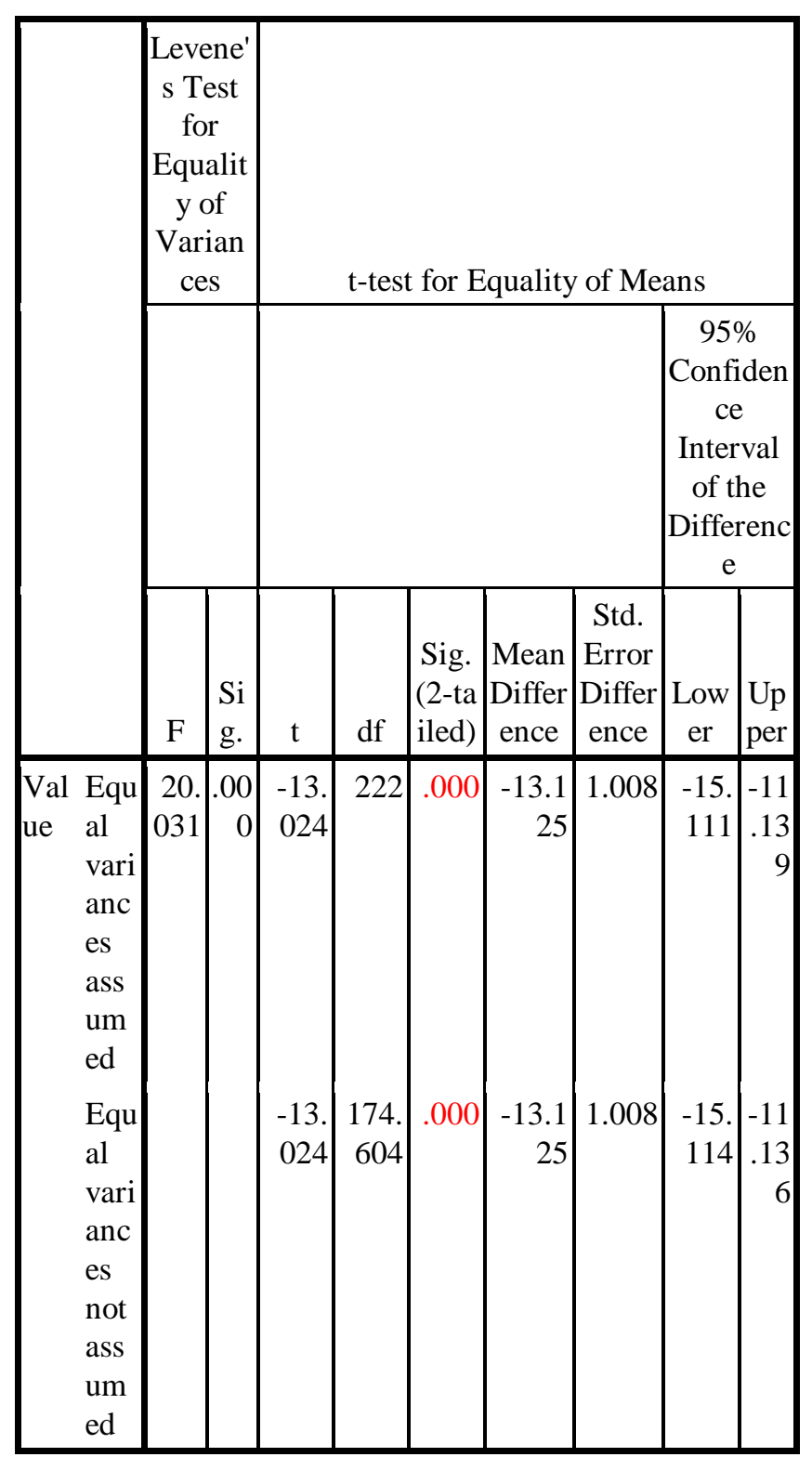

As for Sig (2 tailed) or $\mathrm{p}$ value, the $\mathrm{p}$ value is 0,000 which is $<0.05$, meaning that the difference is statistically significant or significant at the probability of 0.05 . Hence, there is a statistically significant difference in the $5 \%$ error rate of treatment simultaneously before and after training in natural resources, technology, innovation, and "Mapalus" culture for members of entrepreneurial groups on the coast.

\section{CONCLUSION}

Based on the quantitative analysis, it is revealed that partially or in bivariate manner as following. First, there are significant differences before and after training on the potential of natural resources in entrepreneurship. Second, there are significant differences before and after training on technology in entrepreneurship. Third, there are significant differences before and after training on innovation in entrepreneurship. Fourth, there are significant differences before and after training on "Mapalus" culture in entrepreneurship, and finally, there are significant differences simultaneously or univariate before and after training about natural resource potential,

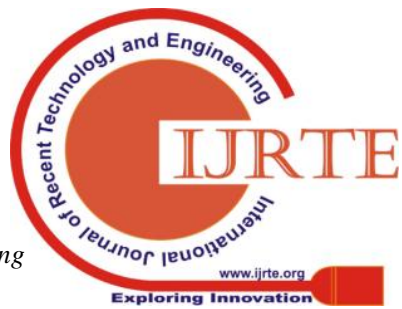


innovation, technology, and "Mapalus" culture in entrepreneurship.

Thus, the entrepreneurship model of people-oriented economy on the coast needs to change the mindset of the people who will try on the coast as a centre of tourism growth by providing skills training for the utilization of coastal natural resource's potential which provides economic value, the utilization of technology in entrepreneurship for the right use of technology and digital technology, entrepreneurial innovation, and accelerate "Mapalus" culture in business groups to strengthen social capital so that business autonomy sustains.

\section{REFERENCESS}

[1] Agung Istri Ari Atu Dewi, A. (2018). Model Pengelolaan Wilayah Pesisir Berbasis Masyarakat: Community Based Development (Vol. 18). https://doi.org/10.30641/dejure.2018.V18.163-182

[2] Bouchon, F., \& Rawat, K. (2016). Rural Areas of ASEAN and Tourism Services, a Field for Innovative Solutions. Procedia - Social and Behavioral Sciences, 224, 44-51. https://doi.org/10.1016/j.sbspro.2016.05.398

[3] Christiaensen, L., \& Martin, W. (2018). Agriculture, structural transformation and poverty reduction: Eight new insights. World Development, 109 413-416. https://doi.org/10.1016/j.worlddev.2018.05.027

[4] Desai, R. M., \& Rudra, N. (2018). Trade, poverty, and social protection in developing countries. European Journal of Political Economy. https://doi.org/10.1016/j.ejpoleco.2018.08.008

[5] Fatma, E. (2015). Development of Sustainable Tuna Processing Industry using System Dynamics Simulation. Procedia Manufacturing, 4, 107-114. https://doi.org/10.1016/j.promfg.2015.11.020

[6] Ghicajanu, M., Irimie, S., Marica, L., \& Munteanu, R. (2015). Criteria for Excellence in Business. Procedia Economics and Finance, 23, 445-452. https://doi.org/10.1016/S2212-5671(15)00388-3

[7] Grabowska, B. S.-, \& Sukiennik, K. (2015). Innovations in e-enterprises on the Polish Market. Procedia Computer Science, 65, 1046-1051. https://doi.org/10.1016/j.procs.2015.09.054

[8] Hamenda, A. (2018). An Integrated Model of Service Quality, Price Fairness, Ethical Practice and Customer Perceived Values for Customer Satisfaction of Sharing Economy Platform. International Journal of Business and Society, 19(3): 709-724

[9] Härting, R.-C., Reichstein, C., \& Schad, M. (2018). Potentials of Digital Business Models - Empirical investigation of data driven impacts in industry. Procedia Computer Science, 126, 1495-1506. https://doi.org/10.1016/j.procs.2018.08.121

[10] Ibrahim, N., \& Verliyantina. (2012). The Model of Crowdfunding to Support Small and Micro Businesses in Indonesia Through a Web-based Platform. Procedia Economics and Finance, 4, 390-397. https://doi.org/10.1016/S2212-5671(12)00353-X

[11] Ivanic, M., \& Martin, W. (2018). Sectoral Productivity Growth and Poverty Reduction: National and Global Impacts. World Development, 109, 429-439. https://doi.org/10.1016/j.worlddev.2017.07.004

[12] Janáková, H. (2015). The Success Prediction of the Technological Start-up Projects in Slovak Conditions. Procedia Economics and Finance, 34, 73-80. https://doi.org/10.1016/S2212-5671(15)01603-2

[13] Kiaušienè, I. (2015). Comparative assessment of women unemployment and poverty in European Union. Intellectual Economics, 9(2), 91-101. https://doi.org/10.1016/j.intele.2015.12.001

[14] Lakshmi, S. R., \& Shaji, T. L. (2016). Transformation of Coastal Settlements Due to Tourism. Procedia Technology, 24, 1668-1680. https://doi.org/10.1016/j.protcy.2016.05.188

[15] Lowder, S. K., Bertini, R., \& Croppenstedt, A. (2017). Poverty, social protection and agriculture: Levels and trends in data. Global Food Security, 15, 94-107. https://doi.org/10.1016/j.gfs.2017.06.001

[16] Maas, L. T., Sirojuzilam, Erlina, \& Badaruddin. (2015). The Effect of Social Capital on Governance and Sustainable Livelihood of Coastal City Community Medan. Procedia - Social and Behavioral Sciences, 211, 718-722. https://doi.org/10.1016/j.sbspro.2015.11.092

[17] Martadwiprani, H., \& Rahmawati, D. (2014). Economic Development as Community Resilience Enhancement in Minapolis Coastal Settlement. Procedia - Social and Behavioral Sciences, 135, 106-111. https://doi.org/10.1016/j.sbspro.2014.07.332

[18] Marwasta, D. (2017). Pendampingan Masyarakat Desa Parangtritis dalam Pengelolaan Kawasan Gumuk Pasir melalui kegiatan Diversifikasi
Usaha Berbasis Sumberdaya Pesisir. Jurnal Pengabdian Kepada Masyarakat (Indonesian Journal of Community Engagement), (Vol 2, No 2 (2017): Maret), 133-145.

[19] Millers, M., \& Sceulovs, D. (2017). Are IT Skills Helpful to Manage Processes in a Small Business? Procedia Computer Science, 104, 235-241. https://doi.org/10.1016/j.procs.2017.01.130

[20] Nurkholis, Nuryadin, D., Syaifudin, N., Handika, R., Setyobudi, R. H., \& Udjianto, D. W. (2016). The Economic of Marine Sector in Indonesia. Aquatic Procedia, 7, 181-186. https://doi.org/10.1016/j.aqpro.2016.07.025

[21] Page, S. J., Hartwell, H., Johns, N., Fyall, A., Ladkin, A., \& Hemingway, A. (2017). Case study: Wellness, tourism and small business development in a UK coastal resort: Public engagement in practice. Tourism Management, $60, \quad 466-477$. https://doi.org/10.1016/j.tourman.2016.12.014

[22] Pärttö, M., \& Saariluoma, P. (2012). Explaining failures in innovative thought processes in engineering design. Procedia - Social and Behavioral Sciences, 41, 442-449. https://doi.org/10.1016/j.sbspro.2012.04.053

[23] Rachmania, I. N., Rakhmaniar, M., \& Setyaningsih, S. (2012). Influencing Factors of Entrepreneurial Development in Indonesia. Procedia Economics and Finance, 4, 234-243. https://doi.org/10.1016/S2212-5671(12)00338-3

[24] Setyowati, N., Rahayu, W., \& Ishartani, D. (2016). Development of Tuna Processed Business in Pacitan District, Indonesia. Aquatic Procedia, 7, 160-165. https://doi.org/10.1016/j.aqpro.2016.07.022

[25] Sosnowski, J. (2014). Precipitating Innovations by Academia and Industry Feedback. Procedia - Social and Behavioral Sciences, 109 113-119. https://doi.org/10.1016/j.sbspro.2013.12.429

[26] Sutawa, G. K. (2012). Issues on Bali Tourism Development and Community Empowerment to Support Sustainable Tourism Development. Procedia Economics and Finance, 4, 413-422. https://doi.org/10.1016/S2212-5671(12)00356-5

[27] Tangkudung, J. P. M., \& Senduk, J. J. (2017). MAPALUS ARISAN SEBAGAI SALAH SATU MODEL KEARIFAN LOKAL MASYARAKAT KECAMATAN KAUDITAN KABUPATEN MINAHASA UTARA. JURNAL LPPM BIDANG EKOSOSBUDKUM, 3(2), 107-123.

[28] Turang, T. I., Suman, A., Mandang, J., \& Soemarno, S. (2012). Kajian Peran Mapalus Dalam Pemberdayaan Masyarakat Di Kota Tomohon. WACANA, Jurnal Sosial Dan Humaniora, 15(4), 1-7.

[29] Weissbrod, I., \& Bocken, N. M. P. (2017). Developing sustainable business experimentation capability - A case study. Journal of Cleaner Production, 142, 2663-2676. https://doi.org/10.1016/j.jclepro.2016.11.009

[30] Wuryaningrat, N. F., Kawulur, A. F., \& Kumajas, L. I. (2017), Examining an Endangered Knowledge Transfer Practice Known as "Mapalus" in an Indonesian Village:Implications for Entrepreneurial Activities and Economic Development, 18(S2), 309 - 322. International Journal of Business and Society.

[31] Xavier, S. R., Ahmad, S. Z., Nor, L. M., \& Yusof, M. (2012). Women Entrepreneurs: Making A Change from Employment to Small and Medium Business Ownership. Procedia Economics and Finance, 4 , 321-334. https://doi.org/10.1016/S2212-5671(12)00347-4

[32] Yamin, S., \& Dartanto, T. (2016). Pengentasan Orang Miskin di Indonesia: Peran Modal Sosial yang Terlupakan. Jurnal Ekonomi dan $\begin{array}{lll}\text { Pembangunan } & \text { Indonesia, } & \text { 17(1), }\end{array}$ https://doi.org/10.21002/jepi.v17i1.656

\section{AUTHORS PROFILE.}

Arie Frits Kawulur affiliated with Economics Department, Economic Faculty, Universitas Negeri Manado, Indonesia. My area of interest is macro and miro economics.

My name is Ramon Arthur Ferry Tumiwab currently affiliated with Management Department, Economic Faculty, Universitas Negeri Manado, Indonesia. My area of interest is economic sustainability.

Merry Christie Natalia Rumagit I am from Economics Department, Economic Faculty, Universitas Negeri Manado, Indonesia. My area of interest is economics and finance. 
APPENDIX:

RESEARCH PRE-TEST POST-TEST INSTRUMENTS

\begin{tabular}{|c|c|c|c|c|c|}
\hline \multirow{2}{*}{$\begin{array}{l}\text { Element / Statement } \\
\text { Variable }\end{array}$} & \multicolumn{5}{|c|}{ Option } \\
\hline & $\begin{array}{l}\text { Strongly } \\
\text { Disagree }\end{array}$ & Disagree & Neutral & Agree & $\begin{array}{l}\text { Strongly } \\
\text { Agree }\end{array}$ \\
\hline
\end{tabular}

1. It has high sea and coastal potential in your village

2. The sea has provided a large income for the family so far

3. Many marine fish products continue to be processed as a source of family income

4. Many agricultural products are processed into a source of family income

5. The tourism potential on the coast has been managed and provided a living for the family so far

6 . The government and village community leaders plan clearly how to exploit the potential of the sea and the coast

7. I can identify economic potential in coastal villages

8. I know the appropriate technology used in coastal villages so far

9. I can provide a variety of products to sell with technology

10. There is a smooth market for marketing goods produced by business groups / communities

11. I am skilled at using technology in the manufacture of products so far

12. I understand the order of the process of making products to produce's quality of a product

13. Many people have switched to using technology to produce products that are competitive so far

14. Both conventional and online marketing skills can be developed

15. There is stakeholder and buyer's satisfaction with the products produced

16. I can act effectively in difficult business conditions such as raw and expensive materials

17. Act creatively in businesses that have difficulty in selling products

18. I optimize the facilities available to produce products are competitive

19. I know technically that a new product needs to be produced

20. Use business analysis with logical thinking in producing competitive products 
21. In the development of my business, I always increase business value in group business

22. Experience and training produce creative thinking skills

23. I have curiosity in running business on the coast

24. I found myself curious in many ways when I joined the business group on the coast

25. I want to help, if there are group members who are afflicted with distress

26. I always maintain good relationships with fellow group members

27. I uphold work together for mutual benefit

28. I am willing to sacrifice for the common good and mutual benefit

29. I know that the area where we live is close to the coast and tourism objects

30. I want to transform into someone who is useful to others

31. I want to learn to be a new entrepreneur

32. It takes time to become an entrepreneur

33. Need material sacrifice and sometimes feelings in group efforts

34. Entrepreneurship knowledge needs to be in life

35. Entrepreneurial skills are always developed throughout life 